\title{
TRANSFORMATIVE ASPECTS OF SUPERVISION
}

\author{
Dace Dolace \\ Latvian Christian Academy (Latvia)
}

\begin{abstract}
The article analyses the most relevant anthropological and transformative tasks of social work supervision in the context of today's risk society, promoted by the process of globalisation with its instrumental rationality, which devalues the significance of the personality in the social system. The article provides the ontological grounds of the transformative function of supervision based on synergic patristic anthropology, and describes the simultaneous vectors of the transformative function in the supervision process: 1) experiential (experience-based) transformative learning, or acquisition of 'practical wisdom'; and 2) anthropological transformation as a process of recreation of true selfidentity. The article conceptually emphasises the decisive influence of the intrinsic quality of the supervisor's personality in the performance of the transformative tasks of supervision, as well as the supervisor's ability to form reciprocity relations with supervisees in the supervision process.

KEY WORDS: transformative supervision, social work, professional identity, anthropological identity, patristic anthropology.
\end{abstract}

\section{Anotacija}

Straipsnyje analizuojami aktualiausi socialinio darbo supervizijos uždaviniai šiandieninès rizikos visuomenès kontekste antropologiniu ir modeliavimo aspektais. Tai nulemta globalizacijos proceso instrumentinio racionalumo, kuris nuvertina asmenybės reikšmę socialinėje sistemoje. Straipsnyje aptartos supervizijos modeliavimo funkcijos, pagrịstos sinergine patristine antropologija, ontologine prieiga, pateikiami šios funkcijos supervizijos procese vektoriai: 1) patirtinis (patirtimi grịstas) modeliavimo mokymasis, arba „praktinès išminties“ igijimas; 2 ) antropologinis modeliavimas, kaip tapatybės atkūrimo procesas. Akcentuojamas supervizoriaus asmenybės savybių poveikis vykdant supervizijos modeliavimo užduotis, jo gebejjimas užmegzti santykius su supervizuojamaisiais supervizijos procese.

PAGRINDINIAI ŽODŽIAI: modeliuojamoji supervizija, socialinis darbas, profesinis tapatumas, antropologinis tapatumas, patristinè antropologija.

DOI: $\underline{\text { http://dx.doi.org/10.15181/tbb.v87i2.2320 }}$

\section{Introduction}

Today's society is characterised as 'risk society'. In defining risk, U. Beck concludes that risk is understood as 'the systematic interaction of society with the threats and dangers posed by the modernisation process' (Beck, 2006; 2009). Risk and uncertainty are products of the phenomenon of economic globalisation, where the hegemony of instrumental rationality (reflected in the search for profitability and maximum benefit) tends to reduce and displace any ethical and anthropological (personality-centred) approach in the caring professions. 
Today, in explaining the impact of societal risks, Habermas' discourse of the concept of 'lifeworld' (Habermas, 1990) is often used in literature (Saenz de Ugarte, Martin-Aranaga, 2011; Brown, 2016). The Habermas model both diagnoses the danger of personality exclusion because of 'system colonisation (depersonalisation process)' and offers a strategy for handling uncertainty and risk using the anthropological potential of the 'lifeworld': cultural values, qualitative communication and the development of personal identity, and self-awareness. This anthropologically centred approach is relevant today in different research into the caring professions.

This article focuses on the possibilities and new tasks of social work supervision (which is an integral part of the social work profession) to implement a personality-centred approach in both supervision and social work, thus promoting the effectiveness of professional work in today's social situation. The approach is in line with today's trend to restart 'client-centred approach' methodology in the social field (Campbell, 2018; Kievišienè, 2020; Washburn, Grossman, 2017; Witkin, 2017; Urponen, 2020).

Social professions are experiencing methodological changes today, focusing on the innovative, anthropological and interdisciplinary content of the caring professions.

In this context, supervision as a reflective and consultative support for social practitioners with the aim of promoting professional growth is increasing in importance in the global environment.

Supervision thus becomes a location where needs for managerial accountability, professional support and innovative transformation meet each other at the level of interpersonal communication. The complexity of clients' problems and challenges experienced by communities continuously evolves and grows; therefore, the caring professions, and simultaneously their supervision, survive definite critical periods, and search for innovative solutions and further development.

Issues of these anthropological, ethical, holistic and especially transformative capacities of supervision in the caring professions have been analysed by Weld (2012; 2021), Fook (2012), Fook and Gardner (2007), and Beddoe and Davys (2016).

The aim of the article is to identify and form the methodological anthropological centre of the transformative function of supervision.

To achieve this goal, successive research steps were taken in integrative practical theological methodology (Lewis, Demarest, 1996): a qualitative empirical study to diagnose the topicality of the research subject in practice; an interdisciplinary analysis and interpretation of the facts and problems identified in the study; a critical reflection of the identified problems from the perspective of patristic an- 
Dace Dolace

thropology; and outlining a practical anthropological strategy for the implementation of the transformative function of supervision.

\section{A descriptive setting of the problem of professional identity in the social professions}

In the period 2019 to 2021, Latvia's social systems and social work organisations were significantly affected by the following processes: 1) the phenomenon of remote communication created by Covid-19; the social problems of vaccination and the general climate of insecurity created by the pandemic; 2) the complicated course of the deinstitutionalisation process in the country; and 3) the administrative-territorial reform in Latvia. Since 1 July 2021, the administrative structure of Latvia changed from a 119 local government model to 43 local governments. This amalgamation of territorial units is not over, and it significantly affects the work of the social services: when institutions merge, work traditions, management and bureaucratic requirements change

To identify the most urgent problems and the critical points of social work (and consequently the pressing tasks of supervision) in the above-mentioned context, research was conducted by the author of this article from 2019 to 2021 in 24 supervision groups of different social specialists in Latvia. In the supervisions, discussions were initiated and questionnaires carried out on the opinions of social specialists (social workers, social rehabilitation specialists, specialists in social entrepreneurship), with the aim of recognising the main expectations, difficulties and types of problems of specialists working in human service organisations, as well as recognising how practitioners understand the content of their human-oriented profession, and what kind of meaning they attribute to their profession. The conclusions are also based on the experience and observations by the author working as a supervisor of social work specialists.

Common critical issues and professional risks encountered by most respondents working in human service organisations are:

1) stress (in some cases, long-lasting and intolerable stress) of employees and customers in the uncertainties caused by change, a persistent state of ignorance and insecurity, and fear of the future;

2) the experience of managerial influence in decision-making (by 'managerialism', we mean here the negative trend of management in combination with ideology to establish a system depriving employees and civil society of decision-making powers);

3 ) the administration's requirement for quick results in social work with a person, without considering the anthropological specifics of social work; 
4) a feeling of diminishing human value (both employee and client) in the social system and in the institution;

5) the low prestige of social work in society;

6) alienation from the social work client due to limited contact;

7) loss of motivation, doubts about the meaning of the work and one's professional identity, alienation from the self.

As a result of this process, employees are more often feeling burnt out, and are choosing to leave social work institutions: in the supervision groups led by the author, an average of two social workers terminated their employment during the last year. As the number of vacancies increases, so does the workload of the remaining employees.

The author also observed law capacity and insufficient skills of self-reflection, and at the same time the desire of specialists to turn to their self-image and selfunderstanding; we can compare this desire with the longing to return to the home that was left a long time ago. Many specialists considered that mentioning the theme of self-image is inappropriate in a professional environment. They have been trained to develop skills in solving a client's social problems, and not to reflect and communicate their own internal problems.

This attaches a particular importance to supervision. The results of the research show a clearly emphasised 'order' for supervision: there is a need for an anthropologically transformative approach, which is related to recreation, healing the self-image, and can be implemented in the context of the reflection of professional activity.

The changing role of supervision in a risk society is emphasised by N. Weld (Weld, 2012), who developed a transformative supervision model in her monograph A Practical Guide to Transformative Supervision for the Caring Professions. Mention should also be made of J. Lawler's study on supervision in the context of managerialism: Motivation and Meaning: The Role of Supervision (Lawler, 2015). It considers how the task of supervision is changing in the context of an increasing emphasis on external rather than self-regulation of employees. It is argued that the increasing reliance on external regulation undermines individual social workers' intrinsic motivation. The role of supervision in supporting social workers is potentially an important element in guarding against this.

It is appropriate to complement the results of our study with some aspects of another study of social work practice, carried out by J. Fook and F. Gardner. In searching for possibilities for practising the critical reflection method in social work, the authors investigate problems of professional practice. Some of them are:

1) a focus on parts, rather than the whole;

2) a focus on outcomes, and hence stress; 
Dace Dolace

3) the tensions between value-based professional practice and economically and technically focused organisations;

4) the need to find ways to continually develop knowledge and practice that fit all the changing and complex context (Fook, Gardner, 2007).

In summarising these results, it is important to note some essential tendencies peculiar to the caring professions today:

1) the invasion of the human concept, influenced by the philosophy of pragmatism. The practical, pragmatic, achievement-oriented individual of modern market-driven society is a typical example of reduced anthropology. This anthropological type has been defined by J. Habermas, calling the practice of such a person an 'instrumental behaviour' that is based on 'instrumental rationality'. Instrumental behaviour is a threat to the peers of a person and to nature, because everything is subjected to achieving only the individual goals of the operating subject, by ignoring communicative activity (Habermas 1990; Young 1989);

2) the tendency to lose man, the disappearance of the person and the lack of qualitative interpersonal communication and solidarity. This process can be designated by the term anthropological emptiness of the concept and practice of the caring professions, characterising social systems in the 20th century.

\section{The context of the modern anthropological crisis}

The turn of the 20th and 21st centuries is characterised by an all-embracing shift in the social, cultural and theological anthropological paradigm. It is connected with the crisis in traditional anthropological views (on the anthropological crisis in the welfare system, see Gūtmane, 2016). A sign of the crisis is the inefficiency of existing knowledge about the human being in situations where one should find answers and solutions to modern social, educational, pedagogical, religious and other problems, in the conditions of the aggressive social changes of the century. The symptoms of the crisis are expressed first in practice. Rapid changes in the human person happen, and new destructive dynamics appear: extreme psychopractices, suicidal terrorism, pseudo-mystical sects, drug addiction, immersion in virtual reality, criminal behaviour, terrorism, and so on. The philosopher and theologian Sergey Horuzhy uses the term 'park of anthropological deviations' to designate these phenomena (Хоружий, 2004). The theoretical crisis in anthropology is characterised by the fact that existing theories and concepts cannot describe and explain this newly emerged dynamic. This also refers to the main basic elements of the European human concept. And now we should admit that this coherent, inte- 
gral scheme, with all its terms, is not working, because it cannot provide an explanation of what really happens with a human being, and cannot provide strategic practices for education, social inclusion, and so on, to overcome the pathological conditions of this human existence.

The philosopher and theologian Constantine Sigov, one of the most prominent interpreters of the work of the French philosopher Emmanuel Levinas, describes an anthropological crisis as a break between ontology and ethics in modern teaching on the human being. Socially anthropological processes are associated with this break that Levinas defines in the 'theory on the disappearance of the human being' (Сигов, 2004).

This weakness of the anthropological factor today is the reason for difficulties in dealing with the tensions between the growing institutionalisation of social processes, economic pressure and exclusion on the one hand, and the necessity for social inclusion, social adaptation and effective interventions on the other.

A niche appears here for developing innovative, anthropologically based methodologies of social work. The anthropological aim of this social professional approach means: 1) to restore the conceptual focus on respect for and value of the human person, to reach a new attitude towards the so-called client, solitary dialogue instead of the formerly passive recipient of service and assistance (the client); 2) to master the competences of formation of self-identity and professional identity; 3 ) to carry out adequate exploration of human needs and resources; and 4) to focus on communication quality, interdisciplinarity, the common good and solidarity.

And in this context, supervision, with its transformational anthropological paradigm, is the most appropriate space today for the recreation of the professional identity, values and competences of different specialists in the social caring professions.

\section{The 'image of man', or the anthropological paradigm as a methodological basis for transformative supervision}

Supervision is an integral part of the social work professions, and as such, on one hand, it should adopt the shape and follow the methodological guidelines of the social profession, and on the other hand, it should become an invaluable agent for the development of the personality of a supervisee, stabilising his self-image and personal identity as a creative centre of professional capability.

The emphasis on the transformative function of supervision is becoming increasingly remarkable (Shohet, 2011). The supervisor N. Weld reveals in her 


\section{Dace Dolace}

monograph the deeper meaning, contacting with the self-identity, of transformative supervision:

'This process enables our true selves to be most evident in everything we do. It is through honesty and openness that we truly connect to others, and supervision, being a protected relational space, is naturally a part of this [...] Our goal in life is to understand what it means to be human and to learn from life and then give this learning back to the world [...] This is an ability to act out that real self in our lives and profession' (Weld, 11-12-2012).

If there is a lack of this deeper 'true self', the human being acquires skills to put a 'social mask' on, staying at the level of outward signs and actions.

It can be concluded from the above that the model of transformative supervision is based on the concept of a holistic person.

The methodological basis of any humanitarian practice and intervention is an understanding of what a person is. Manifestations of reduced human concepts were mentioned earlier: pragmatism, 'instrumental consciousness', the reduction of the human personality to client status, etc. Today, in developing theories of helping interventions, including supervision, researchers should reveal the basic ontology: the concept of anthropology, from which all other methodological elements emerge. Or sometimes the other way round: in the reflection of practices, methods and discourses, the invisible, unconscious but always present image of the human being is defined.

The research works of German authors on the Menschenbild (image of the human being) in supervision and other caring professions (Petzold, 2015; Frühmann, 2000; Nemann, 2015; etc) is characteristic in this regard. R. Schwarz posits:

"A pre-understanding of the concept of human beings develops an integrative model of supervision [...] The underlying "image of man" determines the ethical implications of supervision' (Schwarz, 2009).

Nemann's study of the direct link between human ontology and an adequate model of transformative supervision deserves attention. First, the author describes the typical mentality of modern Western man, characterised by the pursuit of success and problem-solving, omnipotent optimism, a trust in resources, and planning. It also finds expression in supervision as an expectation and a requirement for rational solutions to problems. Nemann concludes that behind this attitude is a '... reduced human image that does not perceive the ambivalence and contradictions of life as true. The "Omnipotent person" is unable to understand and endure suffering, and is unable to show compassion' (Nemann, 2015, p. 29).

These tendencies often appear in supervision; moreover, direct demand for transformation and development dominates here. However, in this case, transformation is impossible due to an anthropological paradox. The author offers an 
adequate holistic ontology of man: the Judeo-Christian concept of man, which reveals the ambivalence and complexity of the personality; man is both a Godcreated personality with endless potential and God's image in himself, but at the same time a vulnerable being touched by destruction, suffering and guilt. According to Nemann, a person's formation (transformation) into a person takes place by experiencing three aspects of existence:

1) non-self-sufficiency or dependence on the relations of the Person of God and love for other men;

2) the dynamics of one's own identity, the ability to understand one's own internal conflict and one's own steps towards inner victory, transformation;

3 ) the experience of transcendence, which is a sacramental experience and is associated with the synergistic presence of the Church in the path of human life. This anthropological model has an impact on supervision: while in professional practice, practitioners in supervision go through their experience of ambivalence together, without denying their vulnerability, but at the same time finding signs of anthropological transformation according to their ontological potential.

Also, N. Weld, one of the leading researchers in the field of transformative supervision, exploring 'transformative changes as a function of supervision' (Weld 2012, p. 10), bases her concept on the theological model of anthropology (Teilhard de Chardin, 1959), and specifically on '... human ontological need and ability to transform through learning in physical, biological, and spiritual processes that increase consciousness, through learning within relational contexts, to awaken to our own divinity and embrace our capacity for transformation' (Weld, 2012, p. 11).

\section{Two vectors of transformative function of supervision}

Two interrelated trends in transformative supervision are currently crystallising:

1. Transformation as building professional identity through the transformation of consciousness: describing this process in supervision, Weld uses the term 'building of personal practice theory' (Weld, 2012, p. 13), which in other words she renames as 'practice wisdom', which leads practitioners back to a deeper understanding of the meaning of their work, back to their professional identity (understanding or revealing who I am as a social worker both in the coordinate system of God's Supreme Order, and consequently, in this place and at this time, in a society of risk and change). To achieve this goal, Weld offers a reflective system for supervision based on critical reflection theory and practice (Fook, Gardner, 2007). Here, the 
Dace Dolace

process of reflection moves from experience gained in the field of practice, where the taught techniques and knowledge were applied, to a deeper understanding of this experience, revealing hidden anthropological factors which are imanent to this experience: intuition, faith, love, values, creativity, spiritual life, etc. In this way, the acquisition of true professional competence takes place, because competence is acquired in the reflection of experience and its theoretical redefinition, making it a personal wisdom or personal practice theory. This is a field of supervision. In contrast with competences, skills are acquired through learning in action. Unreflected, impersonalised practice leads the employee to a routine and crisis of professional identity.

2. Transformation as building a personal anthropological identity, perceiving it as an integral part of the profession, in fact, a centre of professional identity. This is an important thesis in understanding transformative supervision. Weld also highlights the problem of 'the gap between the professional and personal selves', and stresses 'the necessity of bringing congruence of these two selves' (Weld, 2012, p. 40).

Our concept of the transformation of the personal identity based on the anthropological basis is Judeo-Christian patristic synergistic anthropology, a unique holistic view of man as Imago Dei, or the image of God in man, which indicates the ontological potential of the personality.

Patristic anthropology based on the theology of St Paul (Romans 8; Galatians 5) also accentuates the border line between two anthropological modes of personality:

1) anthropos pneumatikos: 'spiritual man' or 'inner, intrinsic man', who has acquired through the Church sacraments the capacity of the spiritual mind ( $n \bar{u} s)$, 'the wisdom', the 'new reborn person in the Holy Spirit, capable of understanding divine logic and capable of embodying it in situations of social ministry,

2) anthropos psihikos: 'psychic or soulish man', whose mind, rationality, is focused on the outside world and the senses.

In explaining the concept of transformation in the paradigm of patristic anthropology, we talk about the experience of the 'ontological auto-transformation' of the personality (Хоружий, 2004), the goal of which is the deification (in Greek theosis) of the human through his uniting with God. The inner content of transformation is the transition from the psychic anthropological mode to the spiritual or sacred anthropological mode.

Regarding the problems identified in our study, the following angle of anthropological transformation, based on a patristic interpretation of the Bible, is important: 
'Do not conform to the pattern of this world (sishematizesthe), but be transformed (metamorfüsthe), by the renewing of your mind (nūs), then you will be able to test and approve what God's will is' (Romans 12: 2).

The Greek term 'transformation, changing, altering' is expressed by the opposition of theological terms: morfēe, 'essential form of existence' versus shèma, 'outer outlook, outer form or structure sensed by the senses $>$ a figure or position in dance > outfit, clothing' (Theological Dictionary of the New Testament, 1971, pp. 954-955). Schema here serves as a symbol for outer socialisation, which can be characterised as putting on a social mask and acquiring specific social roles, not changing the orientation of one's personality. Without anthropological criteria, the solutions in social work may stay at the level of this outer schema.

In opposition to these schematically adaptive changes, the goal of anthropological transforming is the emergence of new forms of essence. As a result, a person adapts in his or her new mode of existence what Church theology calls differently: a person's sacred, sacramental, ecclesial status. In the Christian Orthodox understanding, the spirituality of the human being has always been ecclesio-centric, as only the Church is the locus where the ontological joining with Christ is possible. J. Zizioulas describes it as the 'mode of a person's Eucharistic being' (Zizioulas, 1985).

In conclusion, it would be appropriate to clarify the term anthropological identity, which has been defined in interdisciplinary studies as 'conformity of the subject to a source, out of which comes the entirety of one's behavioural norms, and even deeper, as an awareness of one's belonging to some more universal wholeness, which contains the discourse of legitimisation of a person' (Миненков/ Minenkov, 2004).

In reformulating transformative supervision according to the criterion of anthropological identity, there emerges in the centre the following functions of caritative social work: to form or to renew a person's identity of integrity (wholeness) by preventing the personality's inner destruction and ethical pathologies, which are the inner cause of social deviations, and by leading a person in understanding more universal spiritual and ethical causations in personal interrelations with the level of meanings. This contributes to the formation of one's sacred identity (belonging), finding a point of reference for one's own identity.

As has already been mentioned, it anticipates the transformation of the anthropological mode. If there is a lack of this deeper 'source of norms', the human being acquires skills to put a 'social mask' on, staying at the level of outer signs. The formation of the anthropological identity as a strategic task for transformative supervision means developing the capability of transcending (in Latin transcendentia, 'crossing-over, trespassing'). The practical theologian J. Hull describes 


\section{Dace Dolace}

this ability in the following way: 'That is ability and skill to transcend one's own biological reality, respectively, ability to make one's own biological organism into an instrument for achieving over-biological and over-instinctive goals. This kind of transcending potential contains ability of abstract and critical reasoning, imagination, empathy, ability to perceive spiritual symbols and capacity to integrate experience and knowledge by confirming all what is meaningful, what is higher than individual feeling of pleasure or pain' (Hull, 2003).

Definition marks human transcendence, first of all as overcoming modern individualism, and secondly as a qualitative revolution of 'instrumental thinking': not to make the people around one into instruments for achieving one's own goals, but to instrumentalise one's own natural anthropological dimension to reach higher goals.

\section{The supervisor's personality in the relational space of supervison}

The process of transformative supervision is the pursuit of mutual trust and truthfulness by those involved. The process of approaching and experiencing the truth in the relational space of supervision is an important catalyst for the reciprocal transformation of participants in supervision (Weld, 2012). In this context, it is important to highlight the special role of the supervisor's personality and authority. The supervisor has the main responsibility for initiating transformative processes, but his main tool is not methods of supervision and communication techniques, but the quality of his spiritual life and the personal path to anthropological and professional transformation. The state of the spiritual mind of the supervisor, which can distinguish the spiritual and egocentric modes of man, is a real agent of change of the other personality. The supervisor is the initiator and restorer of mutual and dialogical communication, implementing the following anthropological principles of qualitative transformative communication:

1) the main condition of ethical dialogical communication: recognition of the potential spiritual 'self' of the other person;

2) the other person is a secret to us. In dialogue, thanks to the quality of relationships, the personality unfolds; it can allow its mystery to be seen. The basic law in supervision is to avoid a dominating activity, which is expressed as efforts to help others by calming down, teaching, and convincing about spiritual issues (before this person has even asked for it!). A condition of the transformative approach is devotion, listening and concentrating on the other, in that way coming closer to a break in relationships when an individual, who has enclosed himself/herself in suffering, gives an impulse for a serious conversation about things that touch the core of his personality; 
3) qualitative communication is one in which acceptance of a person takes place that is based on a conviction of the dignity (the image of God in the personality) of that person, not reducing the person to his actual state. The wisdom of love exists in the ability to see in dynamic unity both the person's spiritual potential and actual existence, as well as in the ability to critically separate and evaluate this actual behaviour, not losing hope and respect.

These challenges require the further development of the concept and practice of supervision, updating the transformative, ethical and anthropological functions of supervision. Supervision continues to develop as a tool for professional growth.

\section{Conclusions}

1. Empirical research in the social work environment has highlighted clearly the fatigue of employees' personalities and a loss of personal identity today in a society of risk and change. This marks the anthropological tasks of supervision.

2. The process of supervision is determined by the anthropological concept or understanding of human nature. Patristic anthropology offers a possibility for the ontological auto-transformation of the personality, which becomes the deepest content of transformative supervision along with external changes in the practice of the practitioner.

3. Internal personality change is a methodological condition for the development of the professional identity and competence. Supervision is a moral and dialogical 'space' of relationship, in which it is possible to set road signs to the ontological essence of an employee's personality.

4. The transformative function of supervision is determined by the spiritual qualities of the supervisor's personality, and the ability to implement reciprocity in relationships.

\section{References}

Beck, U. (2006). Living in the World Risk Society. Economy and Society, Vol. 35, No. 3, p. 329-345. Available from: https://doi.org/10.1080/03085140600844902

Beck, U. (2009). World at Risk. Cambridge: Polity.

Beddoe, L., Davys, A. (2016). Challenges in Professional Supervision: Current Themes and Models for Practice. London: Jessica Kingsley Publishers.

Brown, P. (2016). From Rationalities to Lifeworlds: Analysing the Everyday Handling of Uncertainty and Risk in Terms of Culture, Society and Identity. Health, Risk \& Society, Vol. 18, p. 335-347. Available from: https:// www.tandfonline.com/doi/full/10.1080/13698575.2016.1271866

Campbell, J. (2018). Person-centered Theory and Considerations for Counselling Practice and Teaching. Global Engagement and Transformation, Vol. 2, No. 1. Available from: https://scholarworks.iu.edu/journals/index. php/joget/article/view24394 


\section{Dace Dolace}

Fook, J. (2012). Foreword. In N. Weld. A Practical Guide to Transformative Supervision for the Helping Professions. Amplifying Insight. London and Philadelphia: Jessika Kingsley Publishers, p. 9-17.

Fook, J., Gardner, F. (2007). Practicing Critical Reflection. A Resource Handbook. Berkshire: Open University Press.

Frühmann, R. (2000). Menschenbild und Verhaltenstherapie. In G. Stumm, A. Pritz (eds.). Wörterbuch der Psychotherapie. Vienna. Available from: https://doi.org/10.1007/978-3-211-99131-2 1151

Gūtmane, S. (2016). Anthropological Crisis as the Demolisher of Welfare System in Democracy. Scientific proceedings 4. The innovative Content of Caritative Social Work. Jūrmala: Latvian Christian academy, p. 21-28.

Habermas, J. (1990). Moral Consciousness and Communicative Action. Cambridge: MIT Press.

Hull, J. M. (2003). A Spirituality of Disability: The Christian heritage as both problem and potential. Studies in Christian Ethics, Vol. 16, No. 2, p. 21-35.

Kievišienè, J. (2020) Client-centered Approach in Social Work - the Healing Power of Empathy. Scientific proceedings 6. Client and Human Dignity. Jūrmala: Latvian Christian academy, p. 31-39.

Lawler, J. (2015). Motivation and Meaning: The Role of Supervision. Practice. Social Work in Action, Vol. 27, No. 4: The Supervision of Social Work Practice, p. 265-275. Available from: https://doi.org/10.1080/09503 153.2015 .1048056

Lewis, G. R., Demarest, B. A. (1996). Integrative Theology. Michigan: Zondervan.

Nemann, M. (2015). Wider die Tyrannei des Erfolgs und der Machbarkeit-Supervision im Horizont eines christlichen Menschenbildes. Supervision in der Beobachtung: Forschungs- und praxisbezogene Perspektiven, p. 27-37. Verlag Barbara Budrich.

Petzold, G. H. (2015). Die Menschenbilder in der Psychotherapie. Interdisziplinäre Perspektiven und die Modelle der Therapieschulen. Aisthesis Verlag Bielefeld.

Saenz de Ugarte, L., Martin-Aranaga, I. (2011). Social Work and Risk Society: The Need for Shared Social Responsibility. European Journal of Social Work, Vol. 14, No. 4, p. 447-462. Available from: https://doi.org /10.1080/13691457.2010.500478

Schwarz, R. (2009). Supervision und professionelles Handeln Pflegender. Supervision-berufsbezogene Beratung. VS Verlag für Sozialwissenschaften, p. 143.

Shohet, R. (ed.) (2011). Supervision as Transformation. London: Jessika Kingsley Publishers.

Teilhard de Chardin, P. (1959). The Phenomenon of Man. London: Williams Collins Sons and Co Ltd.

Theological Dictionary of the New Testament. (1971). Vol. 7. In G. Kittel, G. Friedrich (eds.). Grand Rapids. Michigan: Wm. B. Eerdmans Publishing Company, p. 954-955.

Urponen, K. (2020). Professional-centered and Client-oriented Social work. Scientific proceedings 6. Client and Human Dignity, p. 21-30. Jūrmala: Latvian Christian academy.

Zizioulas, J. (1985). Being as a Communion: Studies in personhood and the Church. London: Darton, Longman \& Todd.

Washburn, A. M., Grossman, M. (2017). Being with a Person in Our Care: Person-centered Social Work Practice that is Authentically Person-centered. Journal of Gerontological Social Work, Vol. 60, No. 5, p. 408-423. Available from: https://doi.org/10.1080/01634372.2017.1348419

Weld, N. (2012). A Practical Guide to Transformative Supervision for the Helping Professions. Amplifying Insight. London and Philadelphia: Jessika Kingsley Publishers.

Weld, N. (2021). Transformative Supervision. In K. O’Donoghue, L. Engelbrecht (eds.). The Routledge International Handbook of Social Work Supervision, 1st edition. London: Routledge. Available from: https:// www.taylorfrancis.com/books/edit/10.4324/9780429285943/routledge-international-handbook-socialwork-supervision-kieran-donoghue-lambert-engelbrecht?refId=35688047-e99b-47e7-9c58-829abd959800

Young, R. E. (1989). A Critical Theory of Education: Habermas and our children's future. Hertfordshire: Harvester Wheatsheaf.

Witkin, S. (2017). Transforming social work: Social constructionist reflections on contemporary and enduring issues. London: Palgrave (Practice Theory in Context).

Миненков, Г. Я. (2004). Проект идентичности в контексте образования: антропологическая перспектива. Наука и богословие: антропологическая перспектива. Ред. В. Порус. Москва: Библейско-богословский институт св. апостола Андрея, р. 284-298.

Сигов К. (2004). Проблема разрыва между онтологией и этикой в современных учениях о человеке. Православное учение о человеке. Москва-Клин: Синодальная Богословская Комиссия, p. 340-356. 


\section{TRANSFORMATIVE ASPECTS OF SUPERVISION}

Хоружий, С. С. (2004). Православно-аскетическая антропология и кризис современного человека. Православное учение о человеке. Москва-Клин: Синодальная Богословская Комиссия, p. 154-167.

Dace Dolace - associate professor, master of Humanities Sciences (Theology), master of Humanites Sciences (Philosophy), Latvian Christian Academy.

E-mail: kursi@kra.lv 